\title{
Sağlık Çalışanlarının Lider-Üye Etkileşim Düzeylerinin Çeşitli Özellikler Açısından Değerlendirilmesi
}

\author{
Duygu ÜREK, Department of Health Administration, Faculty of Economics and Administrative Sciences, \\ Hacettepe University, Turkey; e-mail: duyguurek@hacettepe.edu.tr \\ Özgür UĞURLUOĞLU, Department of Health Administration, Faculty of Economics and Administrative \\ Sciences, Hacettepe University, Turkey; e-mail: ougurlu@ hacettepe.edu.tr
}

\section{The Evaluation of Health Professions' Leader-Member Exchange Levels in Terms of Various Characteristics}

\begin{abstract}
This study aims to determine the leader-member exchange levels of health professions and reveal whether or not the evaluations related to these levels vary by personal, organizational, and leader's characteristics. To this end, the data obtained from 423 health professions have been evaluated. The results indicate that employees have a medium leader-member exchange level and there are statistically significant differences between employees' evaluations related to leader-member exchange level and its sub-dimensions by age, education, position, status of holding a managerial position, working period in industry, leadership training, hospital type, leader's age, and status of meeting the leader outside the work.
\end{abstract}

Keywords $\quad$ : Leader-Member Exchange, Health Professions, Hospital.

JEL Classification Codes : $\quad$ M10.

\section{$\ddot{\mathbf{O z}}$}

$\mathrm{Bu}$ araştırmanın amacı; sağlık çalışanlarının lider-üye etkileşim düzeylerini belirleyerek bu düzeylere ilişkin değerlendirmelerinin bireysel, örgütsel ve lidere ilişkin özellikler açısından farklılık gösterip göstermediğini ortaya koymaktır. Bu kapsamda, 423 sağlık çalışanından toplanan veriler değerlendirilmiştir. Yapılan analizler neticesinde; çalışanların lider-üye etkileşim düzeyinin orta seviyede olduğu ve çalışanların lider-üye etkileşim düzeyi ve alt boyutları ile ilgili değerlendirmelerinin yaş, eğitim, görev, yönetsel pozisyonun olup olmaması, sektörde çalışma süresi, liderlik eğitimi alıp almama, hastane türü, liderin yaşı ve liderle iş dışında bir araya gelip gelmeme durumuna göre istatistiksel olarak anlamlı farklılıklar gösterdiği saptanmıştır.

Anahtar Sözcükler $\quad$ : $\quad$ Lider-Üye Etkileşimi, Sağlık Çalışanları, Hastane. 


\section{Giriş}

Küreselleşme faaliyetleri nedeniyle günümüzde bütün kurum ve kuruluşlar için rekabetin çok yoğun; ekonomik, sosyal, politik, teknolojik ve uluslararası çevre unsurlarının da oldukça hareketli ve belirsiz olduğu bir iş ortamı mevcuttur. Bu durum, sağlık kurumlarının da kendilerini sürekli olarak değiştirmesini ve geliştirmesini kaçınılmaz bir hale getirmektedir. Bulundukları çevre içerisinde sürdürdükleri faaliyetlerin özelliğinden dolayı, çok sayıda farklı kişi ve kuruluşla etkileşim içerisinde olan sağlık kurumlarının sürekli olarak değişen ve gelişen sağlık sektöründe ayakta kalabilmesi için; etkili ve kaliteli hizmet sunması, teknolojiyi ve insan kaynaklarını başarılı bir şekilde yönetmesi, bünyesinde yaşanan sorunlara hızlı ve kalıcı çözümler üretmesi ve kurumun sürekli olarak gelişimini sağlaması gerekmektedir. Tüm bunların gerçekleştirilebilmesi için sağlık kurumlarında güçlü özelliklere sahip liderlerin varlığı oldukça önemlidir.

Sağlık kurumları liderlerinin taşıması gereken özelliklerin yanı sıra, astlarıyla kurdukları etkileşimlerin düzeyi de dikkatle incelenmesi gereken bir diğer konudur. Lider ile ast arasında kurulan ve zaman içinde gelişen bu benzersiz etkileşim ilişkisi literatürde "lider-üye etkileşimi" olarak adlandırılmaktadır (Harris vd., 2007: 92; Yukl, 2010: 146). Liderliğin en çok araştırılan teorilerinden birisi olan (Goertzen \& Fritz, 2004: 3) Lider-Üye Etkileşim Teorisi, liderlerin üyeleriyle geliştirdikleri ilişki türlerinde farklılaşmalarından dolayı diğer liderlik teorilerinden ayrılmaktadır. Bu yüzden de; belirli bir lider ve üye arasındaki benzersiz ilişki, teorinin ilgi odağını oluşturmaktadır (Gerstner \& Day, 1997: 827; Harris vd., 2007: 92; Burton vd., 2008: 52).

Liderler ve astlar arasında kurulan etkileşim ilișkisi; kurumdaki atmosferi etkileyerek pek çok bireysel ve örgütsel çıktı değişkeni üzerinde etki göstermektedir (Kang \& Stewart, 2007: 533; Dulebohn vd., 2012: 1717). Bu nedenle öncelikle, etkileşim ilişkisini etkileyen faktörleri belirlemenin faydalı olacağı düşünülmektedir. Bu bağlamda söz konusu araştırma; sağlık çalışanlarının liderleriyle olan etkileşim düzeyini belirlemek ve bu düzeye ilişkin değerlendirmelerinin bireysel, örgütsel ve lidere ilişkin özellikler açısından farklılık gösterip göstermediğini ortaya koymak için gerçekleştirilmiş olup, araştırma sonuçlarının kurum yöneticilerine astlarıyla etkileşim gerçekleştirirken katkı sağlayacağı düşünülmektedir.

\section{Lider-Üye Etkileşimi Teorisi}

Liderlik, uzun yıllardır hem yönetim hem de örgütsel davranış literatüründe yer edinmiş önemli bir konu alanıdır. Araştırmacılar ve uygulayıcılar için ilgi odağı haline gelen bu önemli kavram, örgütlerin etkinliğini ve verimliliğini artırmada büyük bir role sahiptir. 
Literatürde liderlik hakkında ileri sürülmüş çeşitli yaklaşımların yanı sıra farklı araştırmacılar tarafından yapılmış farklı liderlik tanımları da bulunmaktadır.

Çağdaş liderlik yazınında; liderlerin tutarlı tek bir liderlik tarzı ortaya koyduğu varsayımı, söz konusu yazının en önemli özelliklerinden birisini oluşturmaktadır. Özellikler teorisi, davranışsal yaklaşım, durumsallık modelleri ve amaç-yol teorisi; bir liderlik tarzı sınıflaması yapıldığında liderin bütün astlarıyla ilgili olarak ortalama bir algıya sahip olduğunu kabul etmektedir (Liden \& Graen, 1980: 451). Öte yandan yazında; liderlerin birimlerindeki bütün astlarına tek bir liderlik tarzı sergilediği varsayımına katılmayan bir liderlik teorisi de bulunmaktadır. Bu teori; Dikey Íkili Bağlantı Modeli (Vertical Dyad Linkage Model) olarak isimlendirilmektedir. Danserau ve diğerleri (1975) tarafından geliştirilen model, bütün liderlik çalışmalarına alternatif bir bakış açısı sunmaktadır. Modele göre; örgütteki her birimde gerçekleşen dikey ilişkilerin gerçek dağılımı sadece bu ikili ilişkilerin her birine odaklanarak keşfedilebilir. Bu yaklaşımla birlikte; dikey ikilinin bütün üyeleri, liderlik sürecindeki araştırmaların odağı olmuştur. Kısaca; dikey ikili, lider ve astı birbirine bağlayan süreçleri ifade ettiği için liderlik süreçlerinin incelenmesindeki en uygun analiz birimi olarak kabul edilmektedir (Danserau vd., 1975: 47).

Dikey İkili Bağlantı Modeli, lider ve astlar arasındaki iş ilişkilerini dikey ikili bir perspektif çerçevesinde ele alarak geliştirilmiştir. İngilizce literatürde "Leader-Member Exchange Theory” olarak yeniden adlandırılmış ve Türkçe yazında "Lider-Üye Etkileşimi Teorisi" olarak yerini almıştır. Teori, lider ve üye arasındaki dinamik ilişkiyi açıklamak için geliştirilmiş olup araştırmacılar tarafından lider-üye ilişkilerinin üyenin davranışsal ve duygusal tepkileri üzerindeki etkisini incelemek için kullanılmıştır (Varma vd., 2005: 84).

Lider-Üye Etkileşimi Teorisi’yle; mübadele ilişkisine bağlı olarak neden bir kısım lider ile üyeler arasında daha yakın ve yüksek kaliteli bir lider-üye ilişkisi kurulurken, diğer bir üye grubu ile biçimsel, resmi ve düşük kaliteli bir lider-üye ilişkisinin kurulduğu açıklığa kavuşturulmaktadır (Bolat, 2011: 67). Yapılan çalışmalar örgütsel birimin, liderüye ikilisine bağlı olarak; yüksek kaliteli etkileşim ilişkilerinin olduğu ikililer ve düşük kaliteli etkileşim ilişkilerinin olduğu ikililer olarak farklılaştığını göstermektedir. Bu iki genel ilişki türünden ilki, genişletilmiş ve müzakere edilmiş rol sorumluluklarına sahip olan üyelerin olduğu "iç grup (güvenilir çekirdek kadro-trusted cadre)"; diğeri ise sadece resmi iş sözleşmesine bağlı olan üyelerin olduğu “dış grup (kiralık el-hired hand)” tur (Danserau vd., 1975: 70; Varma vd., 2005: 85; Northouse, 2013: 161-3).

Rofcanin ve Mehtap (2010: 86-7)'a göre; liderlerin her bir üyeyle eşit ve kaliteli ilişkiye sahip olması için sınırlı zaman ve enerjisi vardır. Bu yüzden lider üyelerinden gelecek sadakat, güven, destek ve benzer davranışlar karşılığında bu kaynaklarını "iç grup” "ta yer alan sadece belirli bazı üyeler için kullanmaktadır. Diğer üyelerle arasında ise 
daha fazla sosyal uzaklık vardır ve bu nedenle bu üyeler “ $d$ ş̧ grup” sosyal statüsündedir. Lideri tarafından ayrıcalıklı muamele gören iç gruptaki üyeler; sahip oldukları yeterlilik ve beceriye, ne ölçüde güvenilir olduklarına (özellikle liderleri tarafından izlenmediklerinde) ve birim içinde daha fazla sorumluluk alma istekliliklerine göre seçilmektedirler. Graen ve Cashman'ın 1975 yılında yaptığı çalışmalarda bu iki uç arasında kalan yeni bir grup olduğu ve bu grubun da "orta grup" olarak adlandırıldı̆̆ı ortaya çıkmıştır. Ancak daha sonra yapılan araştırmalar sonucunda; Lider-Üye Etkileşimi Teorisi'ndeki iç grup ve dış grup kavramının yerine artık, ilişki kalitesi ifadesi (yüksek-düşük kaliteli) kullanılmaya başlanmıştır. Bu gelişim, her ilişkinin benzersiz olması temel felsefesiyle de tutarlıdır (Liden \& Graen, 1980: 451-2; Brower vd., 2000: 229).

Yüksek kaliteli lider-üye etkileşim ilişkisinde, liderler üyelerini genellikle beklenenin ötesinde desteklemekte; üyeler de, daha özerk ve sorumluluk isteyen iş faaliyetlerini yerine getirmektedir. Tam tersine, düşük kaliteli lider-üye etkileşim iliş̧ilerinde ise; taraflar arasında nispeten daha düşük bir karşılıklı etki vardır. Liderler üyelere sadece çalışmaları için ihtiyaç duydukları şeyleri sağlamakta, üyeler de sadece işle ilgili olarak belirlenmiş görevler, kurallar, standart prosedürler, liderden gelen resmi talimatlar gibi biçimsel rol gerekliliklerini yerine getirmektedir. Böyle bir uyum gerçekleştiği sürece, üye işiyle ilgili olarak sadece maaş gibi standart faydalar sağlayabilmektedir (Yukl, 2010: 123; Rowe \& Guerrero, 2011: 239).

Lider ve üye arasındaki bu ikili ilişki gelişimi teorik olarak; Blau (1964)'nun geliştirdiği Sosyal Etkileşim Teorisi ile Katz ve Kahn (1978) tarafından geliştirilen Rol Teorisi temeline dayanmaktadır. Lider ve üyelerin rollerini anlamada önemli katkılar sağlayan Rol Teorisi'ne göre; lider; etkileşim sürecinde farklı roller benimseyeceği için, üyeleriyle de farklı davranış biçimleri içerisinde olabilir ve dolayısıyla da farklı ilişkiler geliştirebilir. Örneğin, Mintzberg (1973: 21-2)'e göre bir lider örgütte; akıl danışmanı, müzakereci, girişimci, sözcü, kriz çözümleyicisi veya kaynak dağıtıcısı gibi farklı roller üstlenebilmektedir. Bu yüzden de; örgütte farklı rollerin, farklı lider-üye etkileşimleri ortaya çıkarması kaçınılmaz olmaktadır. Sosyal Etkileşim Teorisi ise, lider ve üyelerin rollerine odaklanmak yerine bu ikili arasındaki etkileşime odaklanmakta; lider ile üyeler arasındaki güç ve etkinin, lider ve üyelerin değerli kaynaklar elde ettiği alternatif etkileşim ortaklarının varlığına nasıl bağlı olduğunu açıklamaktadır (Sparrowe \& Liden, 1997: 523; Kang \& Stewart, 2007: 535). Teoriye göre; sosyal etkileşim süreci içerisinde yer alan lider ve üyeleri arasında farklı etkileşim boyutları ortaya çıkabilmektedir. Örneğin; bir lider-üye etkileşim ilişkisi tarafların projeleri bitirmek için daha fazla çalışmaya istekli olmaları esasına dayanırken, bir diğer ilişki ise iki tarafın da iş arkadaşlarıyla güzel vakit geçirmesi esasına dayanabilir (Greguras \& Ford, 2006: 435). 


\subsection{Lider-Üye Etkileşim Kalitesine Etki Eden Unsurlar}

Lider ve üye arasında oluşacak ilişkinin gelişimi ve kalitesi karmaşık olmakla birlikte pek çok faktöre bağlıdır. Bu faktörler arasında, üyenin performansı ve lider-üye uyumu en önemli unsurlar olarak görülmektedir. Çünkü üye, becerikli ve güvenilir olarak algılandığında ve üyenin değerleriyle tutumları liderinkilerle benzer olduğunda ilişkinin olumlu olması yüksek bir ihtimaldir (Varma vd., 2005: 86; Yukl, 2010: 125).

Dienesch ve Liden (1986: 626); lider ve üyenin ilk etkileşime girdiklerinde sahip oldukları fiziksel özellikler, tutumlar, dış görünüş, yetenekler, kişilik, deneyim ve yaş gibi unsurların tüm lider-üye etkileşim sürecini etkilediğini belirtmektedir. Sparrowe ve Liden (1997: 539-43) ise, etkileşim kalitesinin; üyenin yeteneği ve performansı, beğenme, algılanan benzerlik ve liderlerin üyeleriyle ilgili beklentilerinden etkilendiğini öne sürmektedir. Ayrıca liderin sahip olduğu üye sayısı, örgütsel büyüklük, coğrafik dağılım, görev yönünden karşılıklı bağlılık gibi örgütsel faktörlerin de lider-üye etkileşimini etkilediğini belirtmektedirler.

Öte yandan Jones (2009: 4), lider-üye etkileşiminde üye sadakati, lider ve üye arasında karşılıklı güven, saygı ve zorunluluk, iletişim sıklığı, iletişim tarzı, destekleyici iletişim ve ikili üyelerin yaş, ırk, eğitim, görev süresi ve cinsiyet benzerliği gibi etki ve etkileşim kalıplarının önemli olduğunu tespit etmiştir. Kang ve Stewart (2007: 532) ise, lider-üye etkileşimini etkileyen unsurları; çoğunlukla etkileşimden önce ortaya çıkan lider ve üye özellikleri ya da lider-üye etkileşimi esnasında oluşan lider ve üyelerin davranışları ile ilgili olduğunu ileri sürmektedir. Bunlara ek olarak Northouse (2013: 163) ise; üyenin iç grupta yer almak adına grup için neler yapabileceği üzerine lideriyle görüşmeler yapmaya ve üyenin biçimsel rol sorumluluklarının ötesine geçerek yeni ve farklı görevler üstlenmeye istekli olmasının da bu süreçte önemli olduğunu vurgulamaktadır.

\subsection{Lider-Üye Etkileşimi Teorisi’nin Boyutları}

Lider-Üye Etkileşimi Teorisi’nin çok boyutlu olup olmadığı tartışmalı bir konudur. Ancak literatürde, lider-üye etkileşimine çok boyutlu yaklaşmanın; lider-üye ilişkisini daha doğru betimlediğine ve bu ilişkilerin önemli bireysel ve örgütsel çıktılarla olan ilişkisi hakkında daha bütüncül açıklamalar getirdiğine dair genel bir kanı bulunmaktadır (Liden \& Maslyn, 1998: 44-5; Greguras \& Ford, 2006: 433-4). Bunun nedeni, teorinin temelde Rol ve Sosyal Etkileşim Kuramı'na dayanmasıdır (Dienesch \& Liden, 1986: 624; Liden \& Maslyn, 1998: 44). Buna göre; etkileşim sürecinde lider ile üyenin farklı roller benimsemesi, ikili arasında farklı etkileşim boyutlarının gerçekleşmesi ve bu süreçte pek çok faktörün etkili olması nedeniyle lider-üye etkileşimleri çok boyutluluğu beraberinde getirmektedir. 
Teorinin çok boyutlu olduğunu gündeme getiren ilk araştırmacılar Dienesch ve Liden (1986: 624-5); lider ve üye arasında gerçekleşecek olan etkileşimlerin katkl, sadakat ve duygusal etkileşim olmak üzere üç boyutta incelenebileceğini öne sürmüşlerdir. Bu üçlü boyutlandırmadan hareketle, Liden ve Maslyn (1998: 49-50); güven ve mesleki/profesyonel saygıyı da boyutlandırmaya ekleyerek lider-üye etkileşimini beş boyutta incelemişlerdir. Ancak güvenin sadakat ile ilişkisinden dolayı, güveni sadakat boyutu altında incelemişlerdir.

Katkı (Contribution): İlk olarak Dienesch ve Liden (1986: 624) tarafından ileri sürülen bu boyut; ikilinin karşılıklı amaçları için her bir tarafin sarf ettiği işle ilgili aktivitelerin miktar, yön ve kalite algısı olarak tanımlanmaktadır. İşle ilgili aktivitelerin değerlendirilmesinde önemli olan, söz konusu ikili ilişkide üyenin iş tanımı ya da sözleşmesi içerisinde yer almayan sorumlulukları alma veya burada belirtilmeyen işleri yapma düzeyi ve liderin ise bu eylemlerde bulunması için üyeye gereken kaynak ve firsatları sağlama derecesidir (Liden \& Maslyn, 1998: 50).

Sadakat (Loyalty): Dienesch ve Liden (1986: 625)'in öne sürdüğü bir diğer boyut olan sadakat boyutu; lider-üye ikilisinin diğer tarafın amaçları ve kişisel özellikleri için genel desteğini ifade etmektedir. Boyut, birey için genellikle her durumda tutarlılık sergileyen bir vefakârlık göstergesidir. Sadakat temel olarak, yakın çevredeki dış güçlerle ilgili olarak ikilinin birbirini koruma seviyesiyle ilgilidir. Üyenin göstermiş olduğu yüksek sadakat düzeyinin, liderin üyenin uzun vadedeki gelişimine yönelik girişimlerine de yansıyacağ düşünülmektedir; çünkü lider ilişkinin devamlılığından artık emin olmuştur (Liden \& Maslyn, 1998: 50).

Duygusal etkileşim (Affect): Bu boyut, Dienesch ve Liden (1986: 625) tarafindan ileri sürülen üçüncü boyuttur. Bu boyutta; lider-üye ikilisinin iş veya profesyonel değerlerden ziyade temel olarak birbirleri ile karşılıklı ilgiye dayalı etkileşimi söz konusudur. Lider-üye etkileşiminde duygusal etkileşim diğer boyutlara göre, ikili arasında gerçekleşecek etkileşimlerin sayısını ve tarzını daha ciddi etkilemekte, sonucunda da işyerinde daha sıcak ve arkadaşça bir atmosfer oluşmaktadır.

Mesleki/Profesyonel saygl (Professional respect): Liden ve Maslyn (1998: 50) tarafından eklenen ve son boyut olan profesyonel saygı boyutu ise; ikili ilişkideki her bir tarafın örgütün içinde veya dışında, kendi işinde başarılı olarak oluşturduğu itibar seviyesiyle ilgili algıları ifade etmektedir. Söz konusu bu algılar; bireyle ilgili kişisel deneyim, kişi hakkında örgütün içindeki ve dışındaki bireylerden gelen yorumlar ve kişinin kazanmış olduğu ödüller ya da diğer mesleki başarılar gibi kişiyle ilgili tarihsel verilere dayanabilir. Dolayısıyla, lider ve üyenin mesleki saygıya dair algıları, birbirleri ile çalışmalarından hatta birbirleri ile karşılaşmalarından çok daha önce oluşabilmektedir. 


\subsection{Lider-Üye Etkileşiminin Sağlık Kurumları Açısından Önemi}

Günümüz organizasyonları arasında takım tabanlı yüksek derecede interaktif yapılara geçme yönündeki eğilime rağmen, örgütlerin çok azı var olan hiyerarşik yapıyı elimine edebilmektedir. Söz konusu hiyerarşik yapı aslında, yöneticilere görevlerini yerine getirme konusunda pek çok sınırlılık getirmektedir. Kısıtlı zaman, enerji ve kaynaklar ile piramit örgüt yapısıyla sınırlandırılmış olan yöneticiler bütün astlarıyla eşit ilişkiler geliştirememektedir. Bu anlamda Lider-Üye Etkileşimi Teorisi, son yıllarda liderlik davranışlarını tanımlamak ve bu davranışın sonuçlarını anlamak için ortaya atılmış en yararlı teorilerden biri olarak karşımıza çıkmaktadır. Teoriye göre, liderlerin kendilerine yardım edecek küçük ve güvenilir bir üye grubu oluşturmaları; sahip oldukları kısıtlı zaman, enerji ve kaynakları daha etkili bir şekilde kullanmalarını sağlayarak örgütsel amaçları başarmada en etkili ve en verimli yol olarak kabul edilmektedir (Yu \& Liang, 2004: 253-4; Hooper \& Martin, 2008: 21; Yukl, 2010: 123). Ayrıca yapılan araştırmalarda; liderleriyle yüksek kaliteli etkileşime sahip üyelerin düşük kaliteli lider-üye etkileşimine sahip üyelere göre, daha fazla pozitif iş tutumlarına sahip oldukları ve pozitif davranışlarla daha fazla ilgilendikleri saptanmıştır (Harris vd., 2007: 96; Kang \& Stewart, 2007: 532; Burton vd., 2008: 52; Hooper \& Martin, 2008: 20; Dulebohn vd., 2012: 1726).

Liderlik araştırmalarının yapılmasının ve liderliğin teşvik edilmesinin oldukça önemli olduğu bir sektör olan sağlık sektörü açısından bakıldığında da benzer sonuçların ortaya çıktığı görülmektedir (Göksel \& Aydıntan, 2012: 247; Konja vd., 2012: 3802; Uğurluoğlu vd., 2013: 1). Birçok ülkede en büyük endüstrilerden birini oluşturmas1 nedeniyle; hem çok sayıda insanı istihdam eden işveren niteliği taşıyan hem de ülke ekonomilerindeki büyük bir payı kapsayan sağlık kurumlarının ve sundukları hizmetlerin performansı, toplumsal refah için kritiktir. Çünkü daha sağlıklı toplumlar, daha üretken toplumlar anlamına gelmektedir (Gilmartin \& D'Aunno, 2007: 388). Dolayısıyla sağlık sektörü; etkili liderlik hakkında bilgiye sahip olmanın gerekli olduğu, bu nedenle de lider ve üye arasında gerçekleşen etkileşim ilişkilerinin derinlemesine araştırılmasının büyük önem taşıdığı bir sektör olarak karşımıza çıkmaktadır.

Sağlık kurumları; bünyesinde çok sayıda meslekten kişileri barındıran, tanı, teşhis, tedavi ve rehabilitasyon hizmetlerinin kesintisiz olarak büyük ekipler halinde ve işbirliği içerisinde sunulduğu ve günlük faaliyetlerinin yanı sıra kendi sektör çevresinde ve dış çevrede meydana gelen değişimlere de başarılı bir şekilde yanıtlar vererek hem hayat kurtarmaya hem de hayatta kalmaya çalışan büyük karmaşık yapılardır. Bu yapılar içerisinde insan hayatının söz konusu olduğu karmaşık süreçlerin varlığı ve bu süreçlerin doğru bir şekilde yönetilmesi gerekliliği, kurum genelinde etkin liderliğin hayati bir anlam taşıdığının bir göstergesidir. Personel ve kaynak yetersizliği, hasta beklentilerindeki değişim, yoğun rekabet, tıp ve teknoloji dünyasında meydana gelen hızlı gelişme ve değişimler gibi 
durumlarla başa çıkmaya çalışan sağlık kurumlarında güçlü ve etkin liderlerin varlığı; lider ve üyelerin iyi ilişkiler geliştirerek kurum genelinde takım halinde çalışmanın ve işbirliği içinde olmanın önemini pekiştirmektedir.

\section{Gereç ve Yöntem}

\subsection{Araştırmanın Amacı ve Hipotezleri}

$\mathrm{Bu}$ araştırmanın amacı, sağlık çalışanlarının liderleriyle olan etkileşimlerinin hangi düzeyde olduğunu tespit ederek çalışanların lider-üye etkileşim düzeyleri ve alt boyutları (katkı, sadakat, duygusal etkileşim ve profesyonel sayg1) ile ilgili değerlendirmelerinin bireysel, örgütsel ve lidere ilişkin özellikler açısından farklılık gösterip göstermediğini ortaya koymaktır. Bu doğrultuda oluşturulan araştırma modeli aşağıdaki gibidir (bkz. Şekil 1).

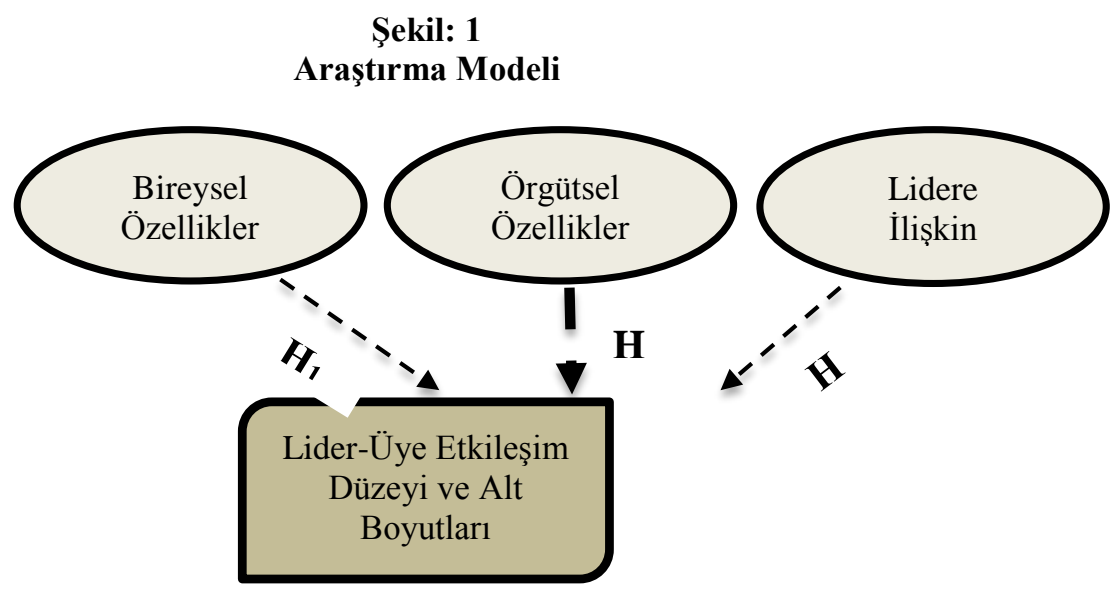

Şekil 1'de yer alan değişkenler ayrıca araştırma hipotezlerinin ortaya konulmasında da bir temel oluşturmaktadır. Bu bağlamda araştırma kapsamında ilgili literatür incelenerek oluşturulan hipotezler aşağıdaki şekildedir:

H1: Sağlık çalışanlarının lider-üye etkileşim düzeyleri ve alt boyutları ile ilgili değerlendirmeleri, bireysel özelliklerine (cinsiyet, yaş, medeni durum, eğitim durumu, hastanedeki görev, yönetsel pozisyonun olup olmamasi durumu, sektörde çalışma süresi ve liderlik eğitimi alıp almama durumu) göre istatistiksel olarak anlamlı farklılıklar göstermektedir. 
H2: Sağllk çalışanlarının lider-üye etkileşim düzeyleri ve alt boyutlart ile ilgili değerlendirmeleri, örgütsel özelliklerine (hastane türü) göre istatistiksel olarak anlaml farkluliklar göstermektedir.

H3: Sağllk çalışanlarının lider-üye etkileşim düzeyleri ve alt boyutları ile ilgili değerlendirmeleri, liderlere ilişkin özelliklere (liderin cinsiyeti, liderin yaşı, liderle çalışma süresi ve liderle iş dışı zamanlarda bir araya gelme durumu) göre istatistiksel olarak anlamll farkllllklar göstermektedir.

\subsection{Veri Toplama Yöntemi}

Araştırmada veri toplama yöntemi olarak anket formu kullanılmıştır. Söz konusu anket formunun ilk bölümünde kişisel ve demografik bilgileri ölçmeye yönelik sorular, ikinci bölümünde ise lider-üye etkileşimi ölçeği yer almaktadır. Anket formunun uygulanmasında yüz yüze görüşme yolu tercih edilmiş olup anketin doldurulması esnasında katılımcılardan, liderlerine ilişkin sorulara bir üst yöneticilerini düşünerek cevap vermeleri istenmiştir.

Kişisel ve Demografik Bilgiler: Bu bölüm, anket formunun ilk kısmı olup katılımcıların kişisel ve demografik bilgilerini ölçmek amacıyla araştırmacılar tarafından hazırlanmıştır. Söz konusu bölümde katılımcının bireysel, örgütsel ve liderine ilişkin özellikler ile ilgili olarak toplamda 12 soru bulunmaktadır.

Lider-Üye Etkileşimi Ölçeği (L ÜE-12): Bu bölüm, anket formunun ikinci kısmı olup lider ve üye arasında gerçekleşen etkileşim düzeyini ölçmeyi amaçlamaktadır. Çok Boyutlu Lider-Üye Etkileşimi Ölçeği/LÜE-12 (Multidimensionality of Leader-Member Exchange/LMX-MDM-12) olarak adlandırılan bu ölçek, Liden ve Maslyn (1998) tarafından geliştirilmiştir. Araştırmada bu ölçeğin tercih edilmesinin nedeni; ölçeğin ilgili literatürde araştırmacılar tarafından daha sık kullanılıyor olması ve lider ile üyeler arasındaki iş ilişkilerinin yanı sıra sosyal ilişkilere de açıklık getirdiği için diğer ölçeklerden daha güçlü olarak kabul edilmesidir. Lider ve üye arasındaki etkileşime çok boyutlu olarak yaklaşan bu ölçek; katkı, sadakat, duygusal etkileşim ve profesyonel saygı olmak üzere 4 boyutu değerlendirmekte ve her bir boyutta bulunan 3'er maddeyle birlikte toplamda 12 maddeden oluşmaktadır. Söz konusu formda, 1 (Kesinlikle Katılmıyorum) ve 5 (Kesinlikle Katılıyorum) arasında değerler alan 5'li Likert tipi ölçek kullanılmıştır.

Toplam ölçek güvenilirliği, Liden ve Maslyn (1998: 64) tarafından .89 olarak hesaplanmıştır. Ölçeğin Türkçe geçerlilik ve güvenilirliği ise Baş ve diğerleri (2010) tarafından yapılmıştır. Bu çalışmada, araştırma kapsamındaki 423 sağlık çalışanının liderüye etkileşimi alt boyutlarına verdikleri yanıtlar üzerinden hesaplanan Cronbach alfa 
katsayılarında; katkı için .81, sadakat için .92, duygusal etkileşim için .92, profesyonel saygı için .91 ve 12 sorunun tümü için ise .96 alfa değerlerine ulaşılmıştır. Bu sonuçlara göre, LÜE-12 önemli bir güvenirlik standardına sahiptir. Hesaplanan güvenilirlik değerlerinin .70 ve daha yüksek olması güvenilirlik için genel olarak yeterli görülmektedir (Hair vd., 2010: 124).

\subsection{Araştırmanın Evren ve Örneklemi}

Araştırma evrenini; Ankara'da metropolitan alan içerisinde faaliyet gösteren kamu ve özel hastanelerden seçilen bir kamu hastanesi ve bir özel hastanede, 16.12.201322.04 2014 tarihleri arasında fiili olarak çalışan hekim, hemşire, diğer sağlık personeli ve idari personel oluşturmaktadır. Söz konusu hastanelerin yatak kapasiteleri, personel sayısı ve dağılımının birbirine yakın olmasına dikkat edilerek seçim yapılmıştır.

Araştırmanın yürütüldüğü tarihlerde özel hastanede toplam 620, kamu hastanesinde ise toplam 600 çalışan fiili olarak görev yapmaktadır. Araştırmada örneklem seçilmeyip evrenin tamamına ulaşılmaya çalışılmıştır. Araştırmanın yürütüldüğü esnada; herhangi bir nedenden dolayı (hastalık, doğum, yıllık izin vs.) izinli olma, vardiya değişimi, araştırmaya katılmayı istememe gibi sebeplerden ötürü, özel hastaneden 212; kamu hastanesinden ise 211 sağlık çalışanından cevap alınabilmiştir. Toplanan anket formları arasında eksik doldurulan herhangi bir form bulunmamakla birlikte toplamda 423 anket formunun geri dönüşü sağlanmıştır.

\subsection{Araştırma Verilerinin Analizi}

Araştırmada tüm istatistiksel analizler SPSS 21.0 kullanılarak gerçekleştirilmiştir. Öncelikle; araştırmaya katılan sağlık çalışanlarının bireysel, örgütsel ve liderlerine ilişkin özellikleriyle ilgili tanımlayıcı bulguları ortaya koymak için frekans ve yüzdelerden, araştırma değişkeni olan lider-üye etkileşim düzeyi ve alt boyutları için ise tanımlayıcı istatistiksel yöntemlerden faydalanılmıştır.

Sağlık çalışanlarının lider-üye etkileşim düzeyi ve alt boyutlarıyla ilgili değerlendirmelerinin bireysel, örgütsel ve lidere ilişkin özellikler açısından farklılaşıp farklılaşmadığını ortaya koymak amacıyla, iki ortalama arasındaki farkın önemlilik testi ve tek yönlü varyans analizi kullanılmıştır. Gruplar arasında anlamlı farklılıklar bulunması durumunda ise; anlamlılığın hangi gruptan kaynaklandığını bulmak amacıyla, Scheffe testinden faydalanılmıştır. Yapılan tüm istatistiksel testlerde alfa düzeyi 0,05 ve 0,01 olarak alınmıştır. 


\section{Bulgular}

\subsection{Tanımlayıcı Bulgular}

Aşağıdaki tablolarda; araştırma kapsamındaki 423 sağlık çalışanına ve liderlerine ilişkin tanımlayıcı bulgular, araştırma değişkeni lider-üye etkileşim düzeyi ve alt boyutlarına ait temel istatistikler ve boyutların birbirleriyle olan korelasyon değerleri yer almaktadır.

Tablo: 1'e göre; araştırmaya katılan sağlık çalışanlarının \%71,9'u kadın, \%51,3'ünün yaşı 34 ve altında, \%69'u ise evlidir. Katılımcıların \%19,4'ünün lisansüstü eğitim derecesi bulunurken, $\% 50,1$ 'i özel hastanede görev yapmaktadır. Katılımcıların \%41,8'inin kurumlarında idari personel olarak çalıştı̆̆ $, \% 56,3$ 'ünün sektörde çalışma süresinin 10 yıl ve altında olduğu tespit edilmiştir. Araştırma kapsamındaki çalışanların $\% 83,7$ 'si şu an görev yaptıkları kurumda herhangi bir yönetsel pozisyonlarının bulunmadığını, \%65,7'si liderlik hakkında eğitim aldıklarını belirtmişlerdir.

Tablo: 1

Araştırmaya Katılan Sağlık Çalışanlarının Tanımlayıcı Özellikleri

\begin{tabular}{llcc}
\hline Değişkenler & & Sayı & \% \\
\hline \multirow{2}{*}{ Cinsiyet } & Kadın & 304 & 71,9 \\
& Erkek & 119 & 28,1 \\
\hline \multirow{2}{*}{ Yaş } & $\leq 34$ & 217 & 51,3 \\
\multirow{2}{*}{ Medeni Durum } & $\geq 35$ & 206 & 48,7 \\
\hline & Evli & 292 & 69,0 \\
& Bekâr & 131 & 31,0 \\
\multirow{2}{*}{ Eğitim Durumu } & İlköğretim & 5 & 1,2 \\
& Lise & 131 & 31,0 \\
& Ön Lisans & 102 & 24,1 \\
\multirow{2}{*}{ Hastane Türü } & Lisans & 103 & 24,3 \\
& Lisansüstü & 82 & 19,4 \\
\hline \multirow{2}{*}{ Hastanedeki Görev } & Özel & 212 & 50,1 \\
& Kamu & 211 & 49,9 \\
\hline \multirow{2}{*}{ Yönetsel Pozisyon } & Hekim & 69 & 16,3 \\
& Hemşire & 111 & 26,2 \\
\multirow{2}{*}{ Sektörde Çalıșma Süresi } & Diğer Sağllk Pers. & 66 & 15,7 \\
& İdari Personel & 177 & 41,8 \\
\hline \multirow{2}{*}{ Liderlik Eğitimi Alıp Almama } & Evet & 69 & 16,3 \\
& Haylr & 354 & 83,7 \\
\hline TOPLAM & $\leq 10$ yll & 238 & 56,3 \\
& $\geq 11$ yll & 185 & 43,7 \\
\hline
\end{tabular}


Tablo: 2'de araştırmaya katılan sağlık çalışanlarının liderlerine ilişkin bazı tanımlayıcı bulgular yer almaktadır. Elde edilen bulgulara göre; çalışanların \%68,6'sının lideri kadın, \%53'ünün liderinin yaşı 41 ve üzeridir. Katılımcıların \%63,8'i liderleriyle 2 yıl ve altında bir süredir birlikte çalıştıklarını, \%35'i liderleriyle iş dışı zamanlarda da bir araya geldiklerini ifade etmişlerdir.

Tablo: 2

\section{Araştırmaya Katılan Sağlık Çalışanlarının Liderlerine İlişkin Tanımlayıcı Özellikler}

\begin{tabular}{|c|c|c|c|}
\hline Değişkenler & & Sayl & $\%$ \\
\hline \multirow{2}{*}{ Liderin Yaşı } & $\leq 40$ & 199 & 47,0 \\
\hline & $\geq 41$ & 224 & 53,0 \\
\hline \multirow{2}{*}{ Liderin Cinsiyeti } & Kadın & 290 & 68,6 \\
\hline & Erkek & 133 & 31,4 \\
\hline \multirow{2}{*}{ Liderle Çalışma Süresi } & $\leq 2 y l l$ & 270 & 63,8 \\
\hline & $>2 y l l$ & 153 & 36,2 \\
\hline \multirow{2}{*}{ İş Dışı Zamanlarda Bir Araya Gelme } & Evet & 148 & 35,0 \\
\hline & Hayır & 275 & 65,0 \\
\hline TOPLAM & & 423 & 100 \\
\hline
\end{tabular}

Tablo: 3

Lider-Üye Etkileşim Düzeyi ve Alt Boyutlarının Ortalama, Standart Sapma ve Korelasyon Değerleri

\begin{tabular}{|c|c|c|c|c|c|c|c|}
\hline & Ort. & $S S$ & Katki & Sadakat & Duygusal Etkileșim & Profesyonel Saygt & Genel L $\ddot{U} E$ \\
\hline Katkı & 3,47 & 1,10 & 1 & & & & \\
\hline Sadakat & 3,47 & 1,17 & $0,732^{* *}$ & 1 & & & \\
\hline Duygusal Etkileşim & 3,61 & 1,17 & $0,759^{* *}$ & $0,852^{* * *}$ & 1 & & \\
\hline Profesyonel Saygl & 3,61 & 1,11 & $0,744^{\text {** }}$ & $0,804^{* * *}$ & $0,849^{* *}$ & 1 & \\
\hline Genel L $\ddot{U} E$ & 3,54 & 1,04 & $0,879^{\text {** }}$ & $0,925^{* *}$ & $0,944^{* *}$ & $0,924^{\text {** }}$ & 1 \\
\hline
\end{tabular}
${ }^{* *} p<0,01$

Tablo: 3'te araştırmaya katılan sağlık çalışanlarının lider-üye etkileşim düzeylerine ilişkin ortalama, standart sapma ve korelasyon değerleri bulunmaktadır. Buna göre; sağlık çalışanlarının lider-üye etkileşimi alt boyutları içerisinde en yüksek ortalamayı profesyonel saygi $(3,61 \pm 1,11)$ ve duygusal etkileşim $(3,61 \pm 1,17)$ alt boyutlarına verdikleri görülmektedir. Katılımcılar en düşük ortalamayı ise sadakat $(3,47 \pm 1,17)$ ve katk1 $(3,47 \pm 1,10)$ alt boyutlarına vermişlerdir. Çalışanların genel lider-üye etkileşimi düzeyine verdikleri puan ortalaması ise 3,54 1 ,04'tür. Araştırmaya katılan sağlık çalışanlarının liderüye etkileşim düzeyleri 5'li Likert Ölçeği ile değerlendirildiğinden; ortalama puanlar "5" değerine yaklaştıkça ilgili boyutun düzeyi en yükseği, "1" değerine yaklaştıkça ilgili boyutun düzeyi en düşüğü göstermektedir. Buna göre, katılımcıların genel lider-üye etkileşim düzeyi puan ortalamasının orta seviyede olduğu söylenebilir. Ayrıca, lider-üye 
etkileşiminin alt boyutları arasında ve bu boyutlar ile genel lider-üye etkileşim düzeyi arasında $(0,732 \leq \mathrm{r} \leq 0,944)$ olumlu yönde ve güçlü düzeyde ilişkiler olduğu saptanmıştır.

\subsection{Hipotezlere İlişkin Bulgular}

Aşağıda; araştırmaya katılan sağlık çalışanlarının lider-üye etkileşim düzeyi ve alt boyutlarıyla ilgili değerlendirmelerini bireysel (cinsiyet, yaş, medeni durum, eğitim durumu, hastanedeki görev, yönetsel pozisyon, sektörde çalışma süresi ve liderlik eğitimi alıp almama), örgütsel (hastane türü) ve lidere ilişkin (liderin cinsiyeti ile yaşı, liderle çalışma süresi ve liderle iş dışı zamanlarda bir araya gelme) özelliklere göre karşılaştıran test sonuçları yer almaktadır.

Tablo: 4'te; katılımcıların lider-üye etkileşim düzeyi ve alt boyutlarını bireysel özelliklere göre karşılaştıran test sonuçları görülmektedir. Buna göre; sağlık çalışanlarının katkı boyutuna ilişkin değerlendirmelerinin yaş $(\mathrm{t}=2,883 ; \mathrm{p}<0,05)$, eğitim durumu $(\mathrm{F}=7,003$; $\mathrm{p}<0,05)$, hastanedeki görev $(\mathrm{F}=9,214 ; \mathrm{p}<0,05)$, yönetsel pozisyonun olup olmaması $(\mathrm{t}=2,054 ; \mathrm{p}<0,05)$, sektörde çalışma süresi $(\mathrm{t}=3,833 ; \mathrm{p}<0,05)$ ve liderlik eğitimi alıp almama durumu açısından $(\mathrm{t}=-2,104 ; \mathrm{p}<0,05)$ istatistiksel olarak anlamlı farklılıklar gösterdiği tespit edilmiştir.

Analiz sonuçlarına göre; 34 yaş ve altındaki katılımcıların katkı boyutuna ilişkin ortalamaları $(3,62 \pm 1,01) 35$ yaş ve üzerindeki katılımcıların ortalamalarına $(3,32 \pm 1,17)$ göre, ilköğretim ve lise derecesinde eğitime sahip olan katılımcıların katkı boyutuna ilişkin ortalamaları $(3,74 \pm 1,06)$ lisansüstü derecesinde eğitime sahip olan katılımcıların ortalamalarına $(3,05 \pm 1,16)$ göre, yönetsel pozisyona sahip çalışanların katkı boyutuna ilişkin ortalamaları $(3,69 \pm 0,92)$ yönetsel pozisyonu olmayan çalışanların ortalamalarına $(3,43 \pm 1,13)$ göre, sektörde çalışma tecrübesi 10 yıl ve altında olan çalışanların katkı boyutuna ilişkin ortalamaları $(3,65 \pm 1,02)$ sektörde çalışma tecrübesi 11 yıl ve üzeri olan çalışanların ortalamalarına $(3,24 \pm 1,16)$ göre ve liderlik eğitimi almış olan çalışanların katkı boyutuna ilişkin ortalamaları $(3,63 \pm 1,07)$ liderlik eğitimi almamış olan çalışanların ortalamalarına $(3,39 \pm 1,11)$ göre daha yüksek bulunmuştur. Ayrıca hekimlerin katk1 boyutuna ilişkin ortalamaları $(2,90 \pm 1,18)$ hemşirelerin $(3,59 \pm 0,97)$, diğer sağlık personelinin $(3,80 \pm 0,83)$ ve idari personelin $(3,50 \pm 1,16)$ ortalamalarına göre daha düşük bulunmuştur.

Katılımcıların sadakat boyutuna ilişkin değerlendirmelerine bakıldığında; bu değerlendirmelerin yaş $(t=2,062 ; p<0,05)$, eğitim durumu $(F=5,455 ; p<0,05)$ ve hastanedeki göreve $(\mathrm{F}=9,837 ; \mathrm{p}<0,05)$ göre istatistiksel olarak anlamlı farklılıklar gösterdiği saptanmıştır. Buna göre; 34 yaş ve altındaki katılımcıların sadakat boyutuna ilişkin ortalamaları $(3,58 \pm 1,18) 35$ yaş ve üzerindeki katılımcıların ortalamalarına $(3,35 \pm 1,16)$ göre 
ve ilköğretim ve lise derecesinde eğitime sahip olan katılımcıların sadakat boyutuna ilişkin ortalamaları $(3,76 \pm 1,17)$ lisansüstü eğitime sahip olan katılımcıların ortalamalarına $(3,13 \pm 1,17)$ göre daha yüksektir. Hekimlerin bu boyuta ilişkin ortalaması $(3,07 \pm 1,19)$ ise; hemşirelerin $(3,83 \pm 0,81)$, diğer sağlı personelinin $(3,79 \pm 0,94)$ ve idari personelin $(3,29 \pm 1,34)$ ortalamalarına göre daha düşüktür.

Duygusal etkileşim boyutu açısından bakıldığında; çalışanların bu boyuta ilişkin değerlendirmelerinin eğitim durumu $(F=2,788 ; p<0,05)$ ve hastanedeki görev $(F=11,329$; $\mathrm{p}<0,05)$ açısından istatistiksel olarak anlamlı farklılıklar gösterdiği belirlenmiştir. Buna göre; ilköğretim ve lise derecesinde eğitime sahip olan çalışanların duygusal etkileşim boyutuna ilişkin ortalamaları $(3,82 \pm 1,15)$ lisansüstü eğitime sahip olan çalışanların ortalamalarına $(3,36 \pm 1,19)$ göre daha yüksektir. Hekimlerin duygusal etkileşim boyutuna ilişkin ortalamaları $(3,29 \pm 1,23)$ ise; hemşirelerin $(3,98 \pm 0,86)$, diğer sağlık personelinin $(3,98 \pm 0,91)$ ve idari personelin $(3,35 \pm 1,30)$ ortalamalarına göre daha düşük bulunmuştur.

Profesyonel saygı boyutu açısından bakıldığında; çalışanların bu boyuta ilişkin değerlendirmelerinin yaş $(\mathrm{t}=2,502 ; \mathrm{p}<0,05)$, eğitim durumu $(\mathrm{F}=3,590 ; \mathrm{p}<0,05)$, hastanedeki görev $(\mathrm{F}=8,143 ; \mathrm{p}<0,05)$ ve sektörde çalışma süresi $(\mathrm{t}=2,079 ; \mathrm{p}<0,05)$ açısından istatistiksel olarak anlamlı farklılıklar gösterdiği tespit edilmiştir. Buna göre; 34 yaş ve altındaki katılımcıların profesyonel saygı boyutuna ilişkin ortalamaları $(3,74 \pm 1,06) 35$ yaş ve üzerindeki katılımcıların ortalamalarına $(3,48 \pm 1,14)$ göre, ilköğretim ve lise derecesinde eğitime sahip olan katılımcıların profesyonel saygı boyutuna ilişkin ortalamaları $(3,82 \pm 1,09)$ lisansüstü eğitim derecesine sahip olan katılımcıların ortalamalarına $(3,32 \pm 1,16)$ göre ve sektörde çalışma tecrübesi 10 yıl ve altında olan çalışanların profesyonel saygı boyutuna ilişkin ortalamaları $(3,71 \pm 1,07)$ sektörde çalışma tecrübesi 11 yıl ve üzeri olan çalışanların ortalamalarına $(3,49 \pm 1,14)$ göre daha yüksektir. Ayrıca, diğer boyutlarda olduğu gibi hekimlerin bu boyuta ilişkin ortalamaları $(3,22 \pm 1,18)$ da; hemşirelerin $(3,86 \pm 0,85)$, diğer sağlık personelinin $(3,96 \pm 0,91)$ ve idari personelin $(3,48 \pm 1,22)$ ortalamalarına göre daha düşük bulunmuştur. 
Tablo: 4

Araştırmaya Katılan Sağlık Çalışanlarının Bireysel Özelliklerine Göre Lider-Üye Etkileşim Düzeylerine İliş̧in Skorları

\begin{tabular}{|c|c|c|c|c|c|}
\hline \multirow[t]{3}{*}{ Değişkenler } & \multicolumn{5}{|c|}{ Lider-Üye Etkileşim Düzeyi ve Alt Boyutları } \\
\hline & Katki & Sadakat & $\begin{array}{l}\text { Duygusal } \\
\text { Etkileşim }\end{array}$ & $\begin{array}{c}\text { Profesyonel } \\
\text { Saygl }\end{array}$ & Genel LÜE \\
\hline & Ort. & Ort. & Ort. $\quad$ SS & Ort. $\quad$ SS & Ort. \\
\hline \multicolumn{6}{|l|}{ Cinsiyet } \\
\hline Kadın & 1,07 & 1,14 & 3,64 & 1,05 & 1,00 \\
\hline \multirow[t]{2}{*}{ Erkek } & 1,19 & $3,46 \quad 1,24$ & 3,52 & $3,51 \quad 1,23$ & $3,49 \quad 1,16$ \\
\hline & $\mathrm{t}=0,012 ; \mathrm{p}=0,991$ & $\mathrm{t}=0,161 ; \mathrm{p}=0,872$ & $\mathrm{t}=0,950 ; \mathrm{p}=0,343$ & $\mathrm{t}=1,253 ; \mathrm{p}=0,211$ & $\mathrm{t}=0,645 ; \mathrm{p}=0,519$ \\
\hline \multicolumn{6}{|l|}{ Yaș } \\
\hline$\leq 34$ & 1,01 & 1,18 & 1,16 & 1,06 & 3,66 \\
\hline \multirow[t]{2}{*}{$\geq 35$} & $3,32 \quad 1,17$ & $3,35 \quad 1,16$ & $3,51 \quad 1,18$ & $3,48 \quad 1,14$ & $3,41 \quad 1,07$ \\
\hline & $\mathrm{t}=2,883 ; \mathbf{p}=\mathbf{0 , 0 0 4 ^ { * }}$ & $\mathrm{t}=2,062 ; \mathbf{p}=\mathbf{0 , 0 4 0 ^ { * }}$ & $\mathrm{t}=1,731 ; \mathrm{p}=0,084$ & $\mathrm{t}=2,502 ; \mathbf{p}=\mathbf{0 , 0 1 3 ^ { * }}$ & $\mathrm{t}=2,487 ; \mathbf{p}=\mathbf{0 , 0 1 3}$ \\
\hline \multicolumn{6}{|l|}{ Medeni Durum } \\
\hline Evli & 1,12 & 1,12 & 3,63 & 3,57 & 3,53 \\
\hline \multirow[t]{2}{*}{ Bekâr } & $3,52 \quad 1,07$ & $3,46 \quad 1,27$ & $3,55 \quad 1,27$ & $3,70 \quad 1,10$ & $3,56 \quad 1,08$ \\
\hline & $\mathrm{t}=-0,622 ; \mathrm{p}=0,534$ & $\mathrm{t}=0,155 ; \mathrm{p}=0,877$ & $\mathrm{t}=0,650 ; \mathrm{p}=0,516$ & $\mathrm{t}=-1,091 ; \mathrm{p}=0,276$ & $\mathrm{t}=-0,226 ; \mathrm{p}=0,821$ \\
\hline Eğitim Durumu & & & & & \\
\hline İlkögretim ve Lise & 1,06 & 1,17 & 3,82 & 3,82 & 3,78 \\
\hline Ön Lisans & 1,05 & 1,04 & 1,11 & 1,02 & 0,94 \\
\hline Lisans & 1,06 & 1,22 & 1,21 & 1,13 & 3,52 \\
\hline Lisansüstü & 3,05 & $3,13 \quad 1,17$ & 3,36 & $3,32 \quad 1,16$ & $3,22 \quad 1,08$ \\
\hline & $\mathrm{F}=7,003 ; \mathbf{p}<\mathbf{0 , 0 0 1}$ & $\begin{array}{l}\mathrm{F}=5,455 \\
\mathbf{p}=\mathbf{0 , 0 0 1}\end{array}$ & $\mathrm{F}=2,788 ; \mathbf{p}=\mathbf{0 , 0 4 0 ^ { * }}$ & $\begin{array}{l}\mathrm{F}=3,590 \\
\mathbf{p}=\mathbf{0 , 0 1 4 ^ { * }}\end{array}$ & $\begin{array}{l}\mathrm{F}=5,338 \\
\mathbf{p}=\mathbf{0 , 0 0 1}\end{array}$ \\
\hline Hastanedeki Görev & & & & & \\
\hline Hekim & 2,90 & 1,19 & 3,29 & 3,22 & 3,12 \\
\hline Hemşire & 0,97 & 0,81 & 0,86 & 0,85 & 0,78 \\
\hline Dĭger Sağlık Pers. & 0,83 & 0,94 & 0,91 & 0,91 & 3,88 \\
\hline İdari Personel & 1,16 & 1,34 & 3,35 & 1,22 & $3,41 \quad 1,16$ \\
\hline & $F=9,214 ; \mathbf{p}<\mathbf{0 , 0 0 1}$ & $\mathrm{F}=9,837 ; \mathbf{p}<\mathbf{0 , 0 0 1}$ & $\mathrm{F}=11,329 ; \mathbf{p}<\mathbf{0 , 0 0 1}$ & $\mathrm{F}=8,143 ; \mathbf{p}<\mathbf{0 , 0 0 1}$ & $\begin{array}{c}\mathrm{F}=10,331 \\
\mathbf{p}<\mathbf{0 , 0 0 1}\end{array}$ \\
\hline Yönetsel Pozisyon & & & & & \\
\hline Evet & 0,92 & 1,04 & 3,72 & 1,08 & 3,65 \\
\hline Hayır & $3,43 \quad 1,13$ & $3,46 \quad 1,20$ & $3,58 \quad 1,20$ & $3,60 \quad 1,11$ & $3,52 \quad 1,07$ \\
\hline & $\mathrm{t}=2,054 ; \mathbf{p}=\mathbf{0 , 0 4 2}{ }^{*}$ & $\mathrm{t}=0,316 ; \mathrm{p}=0,752$ & $\mathrm{t}=0,869 ; \mathrm{p}=0,385$ & $\mathrm{t}=0,625 ; \mathrm{p}=0,533$ & $\mathrm{t}=0,968 ; \mathrm{p}=0,334$ \\
\hline $\begin{array}{l}\text { Sektörde Çalışma } \\
\text { Süresi }\end{array}$ & & & & & \\
\hline$\leq 10$ & 1,02 & 3,56 & 3,65 & 3,71 & 3,64 \\
\hline$\geq 11$ & $3,24 \quad 1,16$ & $3,36 \quad 1,12$ & $3,55 \quad 1,13$ & $3,49 \quad 1,14$ & $3,41 \quad 1,05$ \\
\hline & $\mathrm{t}=3,833 ; \mathbf{p}<\mathbf{0 , 0 0 1}$ & $\mathrm{t}=1,692 ; \mathrm{p}=0,091$ & $\mathrm{t}=0,925 ; \mathrm{p}=0,356$ & $\mathrm{t}=2,079 ; \mathbf{p}=\mathbf{0 , 0 3 8 ^ { * }}$ & $\mathrm{t}=2,286 ; \mathbf{p}=\mathbf{0 , 0 2 3}$ \\
\hline Liderlik Ĕgitimi & & & & & \\
\hline Evet & 1,07 & 1,18 & 3,65 & 1,10 & 3,64 \\
\hline Hayır & $3,39 \quad 1,11$ & 1,16 & 3,58 & 3,55 & 1,04 \\
\hline & $\begin{array}{l}\mathrm{t}=-2,104 \\
\mathbf{p}=\mathbf{0 , 0 3 6}\end{array}$ & $\mathrm{t}=-1,137 ; \mathrm{p}=0,256$ & & $\mathrm{t}=-1,627 ; \mathrm{p}=0,104$ & $\mathrm{t}=-1,455 ; \mathrm{p}=0,146$ \\
\hline
\end{tabular}

Genel lider-üye etkileşimi açısından bakıldığında ise; çalışanların genel lider-üye etkileşimine ilişkin değerlendirmelerinin yaş $(t=2,487 ; \mathrm{p}<0,05)$, eğitim durumu $(\mathrm{F}=5,338$, $\mathrm{p}<0,05)$, hastanedeki görev $(\mathrm{F}=10,331, \mathrm{p}<0,05)$ ve sektörde çalışma süresi $(\mathrm{t}=2,286, \mathrm{p}<0,05)$ 
açısından istatistiksel olarak anlamlı farklılıklar gösterdiği saptanmıştır. Analiz sonuçlarına göre; 34 yaş ve altındaki katılımcıların genel lider-üye etkileşimine ilişkin ortalamaları $(3,66 \pm 1,01) 35$ yaş ve üzerindeki katılımcıların ortalamalarına $(3,41 \pm 1,07)$ göre, ilköğretim ve lise derecesinde eğitime sahip olan katılımcıların genel lider-üye etkileşimine ilişkin ortalamaları $(3,78 \pm 1,04)$ lisansüstü eğitim derecesine sahip olan katılımcıların ortalamalarına $(3,22 \pm 1,08)$ göre ve sektörde çalışma tecrübesi 10 y1l ve altında olan çalışanların genel lider-üye etkileşimine ilişkin ortalamaları $(3,64 \pm 1,03)$ sektörde çalışma tecrübesi 11 yıl ve üzeri olan çalışanların ortalamalarına $(3,41 \pm 1,05)$ göre daha yüksektir. Ayrıca, hekimlerin genel lider-üye etkileşimine ilişkin ortalamaları $(3,12 \pm 1,11)$ da; hemşirelerin $(3,82 \pm 0,78)$, diğer sağlık personelinin $(3,88 \pm 0,80)$ ve idari personelin $(3,41 \pm 1,16)$ ortalamalarına göre daha düşük bulunmuştur. Elde edilen tüm bu bulgular doğrultusunda; kurulan $\mathrm{H}_{1}$ hipotezi yaş, eğitim durumu, hastanedeki görev, yönetsel pozisyonun olup olmaması, sektörde çalışma süresi ve liderlik eğitimi alıp almama değişkenleri açısından kabul edilmiştir.

Tablo: 5

\section{Araştırmaya Katılan Sağık Çalışanlarının Örgütsel Özelliklerine Göre Lider-Üye Etkileşim Düzeylerine İlişkin Skorları}

\begin{tabular}{|c|c|c|c|c|c|c|c|c|c|c|}
\hline \multirow[t]{3}{*}{ Değişkenler } & \multicolumn{10}{|c|}{ Lider-Üye Etkileşim Düzeyi ve Alt Boyutları } \\
\hline & \multicolumn{2}{|c|}{ Katk } & \multicolumn{2}{|c|}{ Sadakat } & \multicolumn{2}{|c|}{$\begin{array}{l}\text { Duygusal } \\
\text { Etkileşim }\end{array}$} & \multicolumn{2}{|c|}{$\begin{array}{c}\text { Profesyonel } \\
\text { Saygl }\end{array}$} & \multicolumn{2}{|c|}{ Genel L $\ddot{U} E$} \\
\hline & Ort. & SS & Ort. & SS & Ort. & SS & Ort. & SS & Ort. & SS \\
\hline \multicolumn{11}{|l|}{$\begin{array}{l}\text { Hastane } \\
\text { Türü }\end{array}$} \\
\hline$\ddot{O z e l}$ & 3,66 & 1,03 & 3,60 & 1,12 & 3,73 & 1,14 & 3,76 & 1,02 & 3,69 & 0,99 \\
\hline \multirow[t]{2}{*}{ Кати } & 3,28 & 1,14 & 3,34 & 1,21 & 3,48 & 1,20 & 3,46 & 1,17 & 3,39 & 1,08 \\
\hline & \multicolumn{2}{|c|}{$\begin{array}{l}\mathrm{t}=3,586 \\
\mathbf{p}<\mathbf{0 , 0 0 1}\end{array}$} & \multicolumn{2}{|c|}{$\begin{array}{l}\mathrm{t}=2,345 \\
\mathbf{p}=\mathbf{0 , 0 2 0}\end{array}$} & \multicolumn{2}{|c|}{$\mathrm{t}=2,182 ; \mathbf{p}=\mathbf{0 , 0 3 0}$} & \multicolumn{2}{|c|}{$\begin{array}{l}\mathrm{t}=2,838 \\
\mathbf{p}=\mathbf{0 , 0 0 5}\end{array}$} & \multicolumn{2}{|c|}{$\begin{array}{l}\mathrm{t}=2,967 \\
\mathbf{p}=\mathbf{0 , 0 0 3}\end{array}$} \\
\hline
\end{tabular}

Tablo: 5'e bakıldığında; sağlık çalışanlarının katkı, sadakat, duygusal etkileşim, profesyonel saygı ve genel $\boldsymbol{L} \ddot{U} \boldsymbol{E}$ 'ye ilişkin değerlendirmelerinin hastane türü açısından istatistiksel olarak farklılaştığı görülmektedir. Buna göre; özel hastanede çalışan katılımcıların katkı $(3,66 \pm 1,03)$, sadakat $(3,60 \pm 1,12)$, duygusal etkileşim $(3,73 \pm 1,14)$, profesyonel saygı $(3,76 \pm 1,02)$ ve genel lider-üye etkileşimine $(3,69 \pm 0,99)$ ilişkin ortalamaları kamu hastanesinde çalışan katılımcıların ortalamalarına göre daha yüksek bulunmuştur. Dolayısıyla, kurulan $\mathrm{H}_{2}$ hipotezi kabul edilmiştir. 
Tablo: 6

Araştırmaya Katılan Sağlık Çalışanlarının Lidere İlişkin Özelliklere Göre Lider-Üye Etkileşim Düzeylerine İliş̧in Skorları

\begin{tabular}{|c|c|c|c|c|c|c|c|c|c|c|}
\hline \multirow[t]{3}{*}{ Değişkenler } & \multicolumn{10}{|c|}{ Lider-Üye Etkileşim Düzeyi ve Alt Boyutları } \\
\hline & \multicolumn{2}{|c|}{ Katkı } & \multicolumn{2}{|c|}{ Sadakat } & \multicolumn{2}{|c|}{$\begin{array}{l}\text { Duygusal } \\
\text { Etkileșim }\end{array}$} & \multicolumn{2}{|c|}{$\begin{array}{l}\text { Profesyonel } \\
\text { Saygl }\end{array}$} & \multicolumn{2}{|c|}{ Genel L $\ddot{U} E$} \\
\hline & Ort. & SS & Ort. & SS & Ort. & SS & Ort. & SS & Ort. & SS \\
\hline \multicolumn{11}{|c|}{ Liderin Cinsiyeti } \\
\hline Kadın & 3,47 & 1,08 & 3,49 & 1,13 & 3,62 & 1,15 & 3,63 & 1,07 & 3,55 & 1,01 \\
\hline Erkek & \multicolumn{2}{|c|}{$\begin{array}{l}\mathrm{t}=-0,023 \\
\mathrm{p}=0,982\end{array}$} & \multicolumn{2}{|c|}{$\begin{array}{l}\mathrm{t}=0,507 \\
\mathrm{p}=0,613\end{array}$} & \multicolumn{2}{|c|}{$\begin{array}{l}\mathrm{t}=0,310 \\
\mathrm{p}=0,757\end{array}$} & \multicolumn{2}{|c|}{$\begin{array}{l}\mathrm{t}=0,323 \\
\mathrm{p}=0,747\end{array}$} & \multicolumn{2}{|c|}{$\begin{array}{l}\mathrm{t}=0,308 \\
\mathrm{p}=0,758\end{array}$} \\
\hline \multicolumn{11}{|l|}{ Liderin Yașı } \\
\hline$\leq 40$ & 3,52 & 1,08 & 3,58 & 1,14 & 3,73 & 1,14 & 3,67 & 1,12 & 3,63 & 1,03 \\
\hline$\geq 41$ & \multicolumn{2}{|c|}{$\begin{array}{l}\mathrm{t}=0,848 \\
\mathrm{p}=0,397\end{array}$} & \multicolumn{2}{|c|}{$\begin{array}{l}\mathrm{t}=1,797 \\
\mathrm{p}=0,073\end{array}$} & \multicolumn{2}{|c|}{$\begin{array}{l}t=2,065 \\
\mathbf{p}=\mathbf{0 , 0 4 0}\end{array}$} & \multicolumn{2}{|c|}{$\begin{array}{l}\mathrm{t}=0,970 \\
\mathrm{p}=0,333\end{array}$} & \multicolumn{2}{|c|}{$\begin{array}{l}\mathrm{t}=1,562 \\
\mathrm{p}=0,119\end{array}$} \\
\hline \multicolumn{11}{|c|}{ Liderle Çalış̧ma Süresi } \\
\hline$\leq 2 y l l$ & 3,43 & 1,10 & 3,43 & 1,18 & 3,60 & 1,17 & 3,58 & 1,12 & 3,51 & 1,05 \\
\hline$>2 y l l$ & \multicolumn{2}{|c|}{$\begin{array}{l}\mathrm{t}=-1,018 \\
\mathrm{p}=0,309\end{array}$} & \multicolumn{2}{|c|}{$\begin{array}{l}\mathrm{t}=-0,941 \\
\mathrm{p}=0,347\end{array}$} & \multicolumn{2}{|c|}{$\begin{array}{l}\mathrm{t}=-0,205 \\
\mathrm{p}=0,838\end{array}$} & \multicolumn{2}{|c|}{$\begin{array}{c}\mathrm{t}=-0,819 \\
\mathrm{p}=0,413\end{array}$} & \multicolumn{2}{|c|}{$\begin{array}{l}\mathrm{t}=-0,806 \\
\mathrm{p}=0,421\end{array}$} \\
\hline \multicolumn{11}{|c|}{$\begin{array}{l}\text { İs Dışı Zamanlarda Bir } \\
\text { Araya Gelme }\end{array}$} \\
\hline Evet & 3,94 & 0,90 & 4,02 & 0,93 & 4,15 & 0,96 & 4,09 & 0,92 & 4,05 & 0,83 \\
\hline Hayır & \multicolumn{2}{|c|}{$\begin{array}{l}\mathrm{t}=6,791 \\
\mathbf{p}<\mathbf{0 , 0 0 1}\end{array}$} & \multicolumn{2}{|c|}{$\begin{array}{l}\mathrm{t}=7,487 \\
\mathbf{p}<\mathbf{0 , 0 0 1}\end{array}$} & \multicolumn{2}{|c|}{$\begin{array}{l}\mathrm{t}=7,390 \\
\mathbf{p}<\mathbf{0 , 0 0 1}\end{array}$} & \multicolumn{2}{|c|}{$\begin{array}{l}\mathrm{t}=6,896 \\
\mathbf{p}<\mathbf{0 , 0 0 1}\end{array}$} & \multicolumn{2}{|c|}{$\begin{array}{l}\mathrm{t}=7,872 \\
\mathbf{p}<\mathbf{0 , 0 0 1}\end{array}$} \\
\hline
\end{tabular}

Tablo: 6'da, sağlık çalışanlarının lider-üye etkileşim düzeyi ve alt boyutlarını lidere ilişkin özelliklere göre karşılaştıran test sonuçları görülmektedir. Analiz sonuçları; katılımcıların katkı, sadakat, profesyonel saygı ve genel LÜE'ye ilişkin değerlendirmelerinin lidere ilişkin özelliklerden sadece liderle iş dışı zamanlarda da bir araya gelme durumuna $\left(\mathrm{t}_{\mathrm{katk}}=6,791, \mathrm{p}<0,05 ; \mathrm{t}_{\text {sadakat }}=7,487, \mathrm{p}<0,05 ; \mathrm{t}_{\mathrm{psayg}}=6,869, \mathrm{p}<0,05\right.$; $\left.t_{\text {genellüe }}=7,872, p<0,05\right)$ göre istatistiksel olarak farklılaştığını göstermektedir. Buna göre; liderleriyle iş dışında bir araya gelen çalışanların katkı boyutuna ilişkin ortalamaları $(3,94 \pm 0,90)$, sadakat boyutuna ilişkin ortalamaları $(4,02 \pm 0,93)$, profesyonel saygı boyutuna ilişkin ortalamaları $(4,09 \pm 0,92)$ ve genel LÜE’ye ilişkin ortalamaları $(4,05 \pm 0,83)$; liderleriyle iş dışında bir araya gelmeyen çalışanların ortalamalarına göre daha yüksek bulunmuştur.

Duygusal etkileşim boyutuna ilişkin değerlendirmelere bakıldığında ise; bu boyutun liderin yaşı $(\mathrm{t}=2,065 ; \mathrm{p}<0,05)$ ve liderle iş dışı zamanlarda da bir araya gelme 
durumu ( $\mathrm{t}=7,390 ; \mathrm{p}<0,05)$ açısından istatistiksel olarak anlamlı farklılıklar gösterdiği tespit edilmiştir. Buna göre; liderinin yaşı 40 ve altında olan çalışanların duygusal etkileşim boyutuna ait ortalamaları $(3,73 \pm 1,14)$ liderinin yaşı 41 ve üzeri olan çalışanların ortalamalarına $(3,50 \pm 1,19)$ göre daha yüksektir. Ayrıca; lideriyle iş dışı zamanlarda da bir araya gelen çalışanların duygusal etkileşim boyutuna ilişkin ortalamaları $(4,15 \pm 0,96)$ liderleriyle iş dışında bir araya gelmeyen çalışanların ortalamalarına $(3,32 \pm 1,17)$ göre daha yüksek bulunmuştur. Elde edilen bu bulgular doğrultusunda; kurulan $\mathrm{H}_{3}$ hipotezi liderin yaş1 ve liderle iş dışı zamanlarda da bir araya gelme değişkenleri açısından kabul edilmiştir.

\section{Tartışma ve Sonuç}

Bu çalışmada elde edilen sonuçlar; araştırmaya katılan sağlık çalışanlarının liderüye etkileşim düzeyi alt boyutları içerisinde en yüksek puanı verdikleri boyutların profesyonel saygı ve duygusal etkileşim, en düşük puanı verdikleri boyutların ise sadakat ve katkı boyutu olduğunu göstermektedir. Profesyonel saygı boyutunun yüksek olması; sağlık çalışanlarının liderlerinin mesleki becerilerine, işe yönelik bilgi ve uzmanlıklarına saygı ve hayranlık duydukları anlamına gelmektedir. Duygusal etkileşim boyutunun yüksek olması ise; sağlık çalışanların liderlerini birey ve arkadaş olarak sevdikleri ve liderleriyle çalışmaktan zevk aldıklarını göstermektedir. Genel olarak bakıldığında; sağlık çalışanlarının liderleriyle arasında ortaya çıkan ve zaman içinde gelişen etkileşim düzeyi ise orta seviyededir. Benzer şekilde; Sivas ilinde bulunan bir devlet hastanesi ile bir üniversite hastanesinde görev yapan 164 hemşirenin katılımıyla gerçekleştirilmiş bir çalışmada da; hemşirelerin en yüksek puan verdikleri boyutun profesyonel saygı, en düşük puan verdikleri boyutun ise sadakat olduğu tespit edilmiştir. Hemşirelerin genel lider-üye etkileşim düzeyleri ise yüksek olarak bulunmuştur (Uğurluoğlu vd., 2013: 11).

Araştırmada; sağlık çalışanlarının lider-üye etkileşim düzeyleri ve alt boyutlarına ilişkin değerlendirmeleri bireysel özelliklerine göre karşılaştırılmıştır. Buna göre yaş açısından bakıldığında; 34 yaş ve altındaki çalışanların lider-üye etkileşim düzeylerinin 35 yaş ve üzerindeki çalışanlardan daha yüksek olduğu belirlenmiştir. Ankara Gazi Üniversitesi Hastanesi'nde çalışan 57 başhemşire ve sorumlu hemşirenin katıldığ 1 bir çalışmada; yaşı 3040 arasında olan hemşirelerin lider-üye etkileşimlerinin en yüksek düzeyde olduğu, ancak hemşirelerin yaşları ilerledikçe lider-üye etkileşim düzeylerinin düştüğü gözlemlenmiştir (Göksel \& Aydıntan, 2012: 258). Benzer şekilde; Uğurluoğlu ve diğerlerinin (2013: 12) hemşireler üzerinde yapmış oldukları çalışmada da, 34 yaş ve altındaki hemşirelerin sadakat boyutu ortalamaları daha yüksek bulunmuştur. Konja ve diğerlerinin (2012: 3808) gerçekleştirmiş oldukları çalışmada da; yaşça büyük olan hastane çalışanlarının, daha genç çalışanlara göre liderleriyle olan etkileşim düzeylerini daha düşük olarak değerlendirdikleri ortaya konulmuştur. Dolayısıyla, daha genç olan ve meslek hayatının başında olan çalışanların lideriyle aralarındaki etkileşim düzeyinin daha yüksek olması; söz konusu 
çalışanların liderleriyle daha iyi anlaştıklarını, liderlerine daha çok bağlı ve sadık olduklarını göstermektedir. Daha yaşlı olan çalışanların lider-üye etkileşim düzeylerinin düşük olması ise; bu çalışanların kurumda ve sektörde geçirdikleri süre ile sahip oldukları tecrübelerin daha fazla olduğu düşünülürse, liderlerini birer rakip olarak gördükleri, liderlerini kabullenme konusunda sorun yaşadıkları ve liderleriyle daha iyi geçinmek için çaba sarf etmek istememeleriyle açıklanabilir.

Sağlık çalışanları eğitim durumları açısından karşılaştırıldığında ise elde edilen sonuçlar; ilköğretim ve lise derecesinde eğitime sahip olan çalışanların liderleriyle aralarında yüksek düzeyde, lisansüstü eğitim derecesine sahip çalışanların ise liderleriyle aralarında düşük düzeyde bir etkileşim ilişkisi olduğunu göstermektedir. Benzer şekilde; Konja ve diğerlerinin (2012: 3809) yapmış oldukları çalışmada da, ilköğretim düzeyinde eğitime sahip olan sağlık çalışanlarının liderleriyle olan etkileşimlerini daha olumlu olarak değerlendirdikleri belirlenmiştir. Bir başka çalışmada da; lise mezunu olan hemşirelerin liderleriyle aralarında yüksek düzeyde, lisans ve ön lisans mezunu hemşirelerin ise liderleriyle aralarında düşük düzeyde etkileşim olduğu; ancak bu farklılığın istatistiksel olarak anlamlı olmadığı saptanmıştır (Kuzucu, 2013: 46). Bu durumun; ilköğretim ve lise derecesinde eğitime sahip çalışanların eğitim seviyelerindeki yetersizlikten dolayı, kendilerini güvende hissedemeyip işlerini kaybetme korkusu yaşıyor olabilecekleri düşünüldüğünde, liderleriyle iyi geçinmeye çalışmalarından kaynaklandığı söylenebilir. Lisansüstü eğitim derecesine sahip çalışanlar açısından bakıldığında ise; söz konusu çalışanların eğitim seviyeleri yüksek olduğu için özgüvenlerinin arttığı, çalışabilecekleri iş imkânlarının fazlalaştığı düşünülürse; liderleriyle iyi geçinmek için çok çaba sarf etmedikleri söylenebilir.

Sağlık çalışanları hastanedeki görevlerine göre karşılaştırıldığında; hekimlerin lider-üye etkileşim düzeyleri hemşire, diğer sağlık personeli ve idari personele göre oldukça düşük bulunmuştur. Hekimlerin liderleriyle etkileşim düzeylerinin daha düşük bulunması; mesleklerinin taşıdığı güçlü özellikler nedeniyle yüksek otonomiye sahip oldukları için hareket alanlarının kısıtlanmasından hoşlanmamaları, karar alıp verirken daha serbest olmak istemeleri ve dolayısıyla da hastanedeki diğer meslek gruplarına göre liderleriyle yüksek seviyede etkileşimler kurmak için çaba sarf etmemeleriyle açıklanabilir.

Yönetsel pozisyon açısından bakıldığında; yönetsel pozisyona sahip sağlık çalışanlarının lider-üye etkileşimi düzeyinin daha yüksek olduğu ortaya konulmuştur. Yönetsel pozisyona sahip çalışanların mevcut pozisyonlarını korumak isteyecekleri ya da daha yüksek pozisyonlara geçme gibi hedeflerinin olabileceği düşünülürse, bu çalışanların liderleriyle daha iyi ilişkiler geliştirmeye çalışmaları normal karşılanabilir. 
Araştırmaya katılan sağlık çalışanları sektördeki çalışma sürelerine göre karşılaştırıldığında; sektörde 10 yıl ve altında çalışma tecrübesi bulunan çalışanların 11 yıl ve üzerinde çalışma tecrübesi bulunan çalışanlara göre liderleriyle olan etkileşim düzeylerini daha yüksek olarak değerlendirdikleri belirlenmiştir. Benzer şekilde; hastane çalışanları üzerinde yapılan bir çalışmada da, toplam çalışma süresi uzun olan çalışanların liderleriyle olan etkileşim düzeylerini daha düşük olarak değerlendirdikleri tespit edilmiştir (Konja vd., 2012: 3808). Çalışanların yaşları ve sektördeki çalışma sürelerinin artmasılyla birlikte; iş ve özel hayatlarında sahip oldukları sorumluluklar artmakta, bu sorumluluklardan ötürü kendilerini daha yorgun ve tükenmiş hissetmekte, sonuç olarak da bu durum liderleriyle olan etkileşim düzeylerine yansıyabilmektedir.

Liderlik eğitimi alma durumu açısından bakıldığında; liderlik eğitimi alan katılımcıların lider-üye etkileşimi düzeyinin katkı boyutuna ilişkin ortalamalarının daha yüksek olduğu saptanmıştır. Hemşireler üzerinde gerçekleştirilen bir çalışmada da, liderlik hakkında eğitim alan hemşirelerin lider-üye etkileşiminin duygusal etkileşim ve profesyonel saygı boyutuna ilişkin ortalamalarının daha yüksek olduğu bulunmuştur (Uğurluoğlu vd., 2013: 13). Dolayısıyla; çalışanların liderlik hakkında eğitim almış olmalarının çalışanlarda liderlik ve lider-üye etkileşiminin önemi hakkında bir farkındalık yaratmış olabileceği düşünülürse, lider-üye etkileşimine ilişkin ortalamalarının daha yüksek çıkması beklenen bir durumdur.

Araştırmada sağlık çalışanlarının lider-üye etkileşimi düzeyi ve alt boyutlarına ilişkin değerlendirmeleri hastane türüne göre de karşılaştırılmış olup özel hastanede görev yapan sağlık çalışanlarının lider-üye etkileşim düzeylerinin daha yüksek olduğu bulunmuştur. Benzer şekilde; Avustralya'da özel ve kamu hastanelerinde görev yapan 1283 hemşire üzerinde yürütülen bir araştırmada, özel hastanede çalışan hemşirelerin kamu hastanesinde çalışan hemşirelere göre liderleriyle olan etkileşimlerinden daha çok memnun oldukları ortaya çıkmıştır (Brunetto vd., 2012: 2249). Bu nedenle; özel hastanede çalışan sağlık personelinin liderleriyle daha iyi anlaştıkları, liderlerine daha çok bağlı oldukları ve liderleriyle olan ilişkilerinden daha çok memnun oldukları söylenebilir. Bu durumun bir nedeni olarak; özel sektörde çalışmanın beraberinde getirebileceği düşünülen işi kaybetme korkusu gösterilebilir. Özel sektörde çalışan kişilerin kamu sektöründe çalışanlara göre kalıcı kadrolarının olmaması nedeniyle, iş güvencelerinin olmadığı ve dolayısıyla da işlerini korumak için liderleriyle daha iyi ve sağlam etkileşimler kurmaya çalıştıkları söylenebilir. Öte yandan; kamu sektöründe liderin rollerinin yasalarla çizilen bir çerçevede olması, liderin rollerini daha sınırlı hale getirmekte ve bu da kamuda lider ve çalışanlar arasında kurulan etkileşimin sınırlı ve düşük düzeyde olmasına neden olabilmektedir. Ancak liderin daha geniş yetkilere sahip olduğu özel sektörde ise, lider çalışanlarıyla daha farklı seviyelerde ve tarzlarda etkileşimler gerçekleştirebilmektedir. Bu durumun bir diğer nedeni olarak da, kamu hastanesi ile özel hastanenin sahip olduğu yönetim dinamikleri, kurum kültürü ve organizasyon yapısındaki farklılıklar gösterilebilir. Söz konusu iki sektörde var olan bu 
kurumsal farklılaşmalar da, lider ve çalışanlar arasında farklı seviyelerde farklı etkileşimlerin ortaya çıkmasında rol oynayabilmektedir.

Araştırmada, sağlık çalışanlarının lider-üye etkileşimi düzeyi ve alt boyutlarıyla ilgili değerlendirmeleri liderlere ilişkin özelliklere göre de incelenmiş olup liderin yaşı ve liderle iş dışı zamanlarda da bir araya gelme durumunun istatistiksel olarak anlamlı farklılıklar gösterdiği saptanmıştır. Yapılan analizler neticesinde, liderinin yaşı 40 ve altında olan sağlık çalışanlarının duygusal etkileşim düzeyleri daha yüksek bulunmuştur. Buna göre; lideri genç olan çalışanlar, liderlerini birey ve arkadaş olarak daha çok sevmekte ve onlarla çalışmaktan da daha çok zevk almaktadırlar. Bununla birlikte, liderleriyle iş dışı zamanlarda bir araya gelen sağlık çalışanlarının lider-üye etkileşim düzeylerinin daha yüksek olduğu tespit edilmiştir. Buna göre; liderle iş dışında görüşmenin, çalışan ve lider arasındaki bağları güçlendirdiği söylenebilir.

Tüm bu bulgulardan yola çıkarak araştırmaya katılan kamu ve özel hastane çalışanları, Lider-Üye Etkileşimi Teorisi'nin temelinde yer alan iç ve dış grup sınıflandırması açısından değerlendirildiğinde; yaşları 34 ve altı, eğitim durumu ilköğretim ve lise, sektörde çalışma süresi 10 yıl ve altında olan, hastanede diğer sağlık personeli ve hemşire olarak görev yapan ve liderleriyle iş dişında da bir araya gelen çalışanların liderlerine daha yakın olan iç grupta yer aldığı; yaşı 35 ve üzeri, eğitim durumu lisansüstü, sektörde çalışma süresi 11 yıl ve üzeri olan, hastanede hekim olarak görev yapan ve lideriyle iş dışında bir araya gelmeyen çalışanların ise liderlerine daha uzak olan dış grupta yer aldığı söylenebilir.

Literatürde de belirtildiği üzere; diğer sektörlerdeki kurumlara oranla daha farklı, hassas ve karmaşık bir hizmet sunumu gerçekleştiren sağlık kurumlarında lider ile astlar arasında kurulan ve zaman içinde gelişen etkileşim daha da çok önem taşımaktadır. Çünkü lider ve astlar arasında yaşanacak herhangi bir ilişki veya iletişim bozukluğu ya da bunların sebep olacağı çatışmalar sağlık hizmetinin kalitesini etkileyerek hizmeti kullanacak kişinin sağlık durumuna yansıyabilmektedir. Bu nedenle; lider ile astlar arasındaki etkileşim düzeyi ve alt boyutlarının hangi özellikler (bireysel, örgütsel ve lidere ilişkin) açısından farklılık gösterip göstermediğinin ortaya konması sağlık kurumları açısından önem taşımaktadır.

Elde edilen sonuçlara bakıldığında öncelikle, kurumlarda yönetici pozisyonundaki kişilerin; astlarının duygu, düşünce, ihtiyaç ve beklentilerine değer veren, astlarıyla yüksek kalitede ilişkiler geliştirmeye özen gösteren, astlarının geleceklerini anlamlı kılacak kariyer planlarına önem veren, astları arasında adaleti gözeten, astlarına saygı gösteren ve astları için huzurlu ve tatmin edici iş ortamı yaratmaya çalışan kişiler olması gerektiği söylenebilir. Yapılan araştırmalar (Kang \& Stewart, 2007: 532; Dulebohn vd., 2012: 1726); lideriyle yüksek kalitede etkileşim düzeyine sahip çalışanların daha fazla 
pozitif iş tutumlarına sahip oldukları ve pozitif davranışlarla daha fazla ilgilendiklerini ortaya koymaktadır ki, bu kapsamda liderlere düşen görevler; çalışma ortamı ve şartlarını iyileştirmek, çalışanları arasında görev ve ödül dağıtımında adaletli davranmak, çalışanlarla aralarında karşılıklı destek, güven, saygı ve anlayışa dayalı ilişkiler geliştirmek, geleneksel yöntemlerin aksine çalışanları daha fazla memnun edip motive edecek modern liderlik tarzları sergilemektir.

Liderlik eğitimi almış çalışanların liderleriyle olan etkileşimlerinin yüksek düzeyde olduğu göz önüne alındığında, kurumlarda liderlik eğitimlerine daha fazla önem verilmesi gerektiği söylenebilir. Ayrıca araştırmada, liderleriyle iş dışı zamanlarda da bir araya gelen çalışanların lider-üye etkileşim düzeylerinin daha yüksek olduğu saptanmıştır. Bu sonuç doğrultusunda, yöneticilerle çalışanları iş dışında bir araya getirecek ve birbirlerini daha iyi tanımalarına fırsat verecek yılbaşı, bayram gibi özel gün kutlamaları, yemek, piknik, parti, kermes gibi sosyal etkinliklerin düzenlenmesi kurum yöneticilerine sunulabilecek bir diğer öneridir.

\section{Kaynakça}

Baş, T. \& N. Keskin \& İ.S. Mert (2010), "Lider Üye Etkileşimi (LÜE) Modeli ve Ölçme Aracının Türkçe'de Geçerlik ve Güvenilirlik Analizi”, Ege Akademik Bakış, 10(3), 1013-1039.

Blau, P.M. (1964), Exchange and Power in Social Life, New York: Wiley.

Bolat, O.İ. (2011), "Lider Üye Etkileşimi ve Tükenmişlik İlişkisi”, “İ̧̧ Güç” Endüstri İlişkileri ve Insan Kaynaklart Dergisi, 13(2), 63-80.

Brower, H.H. \& F.D. Schoorman \& H.H. Tan (2000), “A Model of Relational Leadership: The Integration of Trust and Leader-Member Exchange”, Leadership Quarterly, 11(2), 227 150.

Brunetto, Y. vd. (2012), “Comparing the Impact of Leader-Member Exchange, Psychological Empowerment and Affective Commitment upon Australian Public and Private Sector Nurses: Implications for Retention", The International Journal of Human Resource Management, 23(11), 2238-2255.

Burton, J.P. \& C.J. Sablynski \& T. Sekiguchi (2008), "Linking Justice, Performance, and Citizenship via Leader-Member Exchange”, Journal of Business and Psychology, 23, 51-61.

Danserau, F. \& G. Graen \& W.J. Haga (1975), “A Vertical Dyad Linkage Approach to Leadership within Formal Organizations", Organizational Behavior and Human Performance, 13, 46-78.

Dienesch, R.M. \& R.C. Liden (1986), "Leader-Member Exchange Model of Leadership: A Critique and Further Development", Academy of Management Review, 11(3), 618-634.

Dulebohn, J.H. vd. (2012), “A Meta-Analysis of Antecedents and Consequences of Leader-Member Exchange: Integrating the Past with an Eye toward the Future", Journal of Management, 38(6), 1715-1759. 
Gerstner, C.R. \& D.V. Day (1997), "Meta-Analytic Review of Leader-Member Exchange Theory: Correlates and Construct Issues", Journal of Applied Psychology, 82(6), 827-844.

Gilmartin, M.J. \& T.A. D'Aunno (2007), "8: Leadership Research in Healthcare", The Academy of Management Annals, 1(1), 387-438.

Goertzen, B.J. \& S. Fritz (2004), "Does Sex of Dyad Members Really Matter?: A Review of LeaderMember Exchange", Journal of Leadership Education, 3(2), 3-18.

Göksel, A. \& B. Aydıntan (2012), "Lider-Üye Etkileşimi Düzeyinin Örgütsel Bağl1lık Üzerine Etkisi: Görgül Bir Araştırma”, Süleyman Demirel Üniversitesi İktisadi ve İdari Bilimler Fakültesi Dergisi, 17(2), 247-271.

Greguras, G.J. \& J.M. Ford (2006), “An Examination of the Multidimensionality of Supervisor and Subordinate Perceptions of Leader-Member Exchange", Journal of Occupational and Organizational Psychology, 79, 433-465.

Hair JR., J.F. vd. (2010), Multivariate Data Analysis (7. bs.), New Jersey: Pearson Prentice Hall.

Harris, K.J. \& R.B. Harris \& D.M. Eplion (2007), "Personality, Leader-Member Exchanges, and Work Outcomes", Journal of Behavioral and Applied Management, 8(2), 92-107.

Hooper, D.T. \& R. Martin (2008), "Beyond Personal Leader-Member Exchange (LMX) Quality: The Effects of Perceived LMX Variability on Employee Reactions", The Leadership Quarterly, 19, 20-30.

Jones, J.A. (2009), "Gender Dissimilarity and Leader-Member Exchange: The Mediating Effect of Communication Apprehension”, Emerging Leadership Journeys, 2(1), 3-16.

Kang, D. \& J. Stewart (2007), "Leader-Member Exchange (LMX) Theory of Leadership and HRD: Development of Units of Theory and Laws of Interaction", Leadership \& Organization Development Journal, 28(6), 531-551.

Katz, D. \& R.L. Kahn (1978), The Social Psychology of Organizations (2. bs.), USA: John Wiley \& Sons, Inc.

Konja, V. \& L. Grubic-Nesic \& D. Lalic (2012), "Leader-Member Exchange Influence on Organizational Commitment among Serbian Hospital Workers", Journal of Society for Development in New Net Environment in B\&H, 6(11), 3802-3814.

Kuzucu, E. (2013), Örgütsel Adalet Algısının Örgütsel Vatandaşlık Davranışına Etkisinde Lider-Üye Etkileşiminin Aracılık Rolü Özel Bir Hastanede Çalı̧̧an Hemşireler Üzerinde Araştırma, Yüksek Lisans Tezi, Marmara Üniversitesi Sosyal Bilimler Enstitüsü İşletme Anabilim Dalı Yönetim ve Organizasyon Bilim Dalı, İstanbul.

Liden, R.C. \& G. Graen (1980), “Generalizability of the Vertical Dyad Linkage Model of Leadership", Academy of Management Journal, 23(3), 451-465.

Liden, R.C. \& J.M. Maslyn (1998), "Multidimensionality of Leader-Member Exchange: An Empirical Assessment through Scale Development", Journal of Management, 24(1), 4372.

Mintzberg, H. (1973), “A New Look at the Chief Executive's Job”, Organizational Dynamics, 1, 20 31.

Northouse, P.G. (2013), Leadership: Theory and Practice (6. bs.), USA: Sage Publications. 
Rofcanin, Y. \& Ö. Mehtap (2010), “Implications of Leader-Member Exchange Relationship (LMX)

Theory and Transformational Leadership Dimensions on Subordinate Citizenship Behavior: An Empirical Paper from Turkey with Services Industry Focus”, International Journal of Global Business, 3(1), 83-101.

Rowe, W.G. \& L. Guerrero (2011), Cases in Leadership (2. bs.), USA: Sage Publications, Inc.

Sparrowe, R.T. \& R.C. Liden (1997), "Process and Structure in Leader-Member Exchange", Academy of Management Review, 22(2), 522-552.

Uğurluoğlu, Ö. \& F. Şantaş \& B. Demirgil (2013), “Lider-Üye Etkileşimi ile Tükenmişlik İlişsisis: Hastanelerde Bir Uygulama", Hacettepe Sağllk İdaresi Dergisi, 16(1), 1-21.

Varma, A. \& E.S. Srinivas \& L.K. Stroh (2005), “A Comparative Study of the Impact of LeaderMember Exchange in US and Indian Samples", Cross Cultural Management, 12(1), 8495.

Yu, D. \& J. Liang (2004), “A New Model for Examining the Leader-Member Exchange (LMX) Theory”, Human Resource Development International, 7(2), 251-264.

Yukl, G. (2010), Leadership in Organizations (7.bs.), Upper Saddle River, NJ: Pearson Education, Inc. 